\title{
AN INVESTIGATION INTO SWITCHING VESSEL SIZES FOR EFFICIENT CONTAINER TERMINAL OPERATIONS: A CASE STUDY OF KAOHSIUNG PORT
}

(DOI No: 10.3940/ijme.2021.a1.654)

En-Wei Chang, Manager, Hong Ming Terminal \& Stevedoring Corp. and National Kaohsiung University of Science and Technology, Taiwan and Hui-Huang Tai, Professor, Department of Shipping and Transportation Management, National Kaohsiung University of Science and Technology, Taiwan

KEY DATES: Submitted: 17/06/2020, Final acceptance: 26/11/2020, Published: 25/03/2021

\section{SUMMARY}

Given the continued growth in the size of container ships, major hub ports around the world have carried out large-scale upgrades of their port facilities to attract shipping companies to choose their ports, thereby enhancing the competitiveness of their ports. This study takes Kaohsiung Port as an example and uses the Decision Analytic Network Process (DANP) method to investigate container terminal operations by switching container terminal operations to appropriate new locations. The results of the study indicate that, despite the external issues (such as a lack of deep-water terminals and hinterland in the port area, the upsizing of ships, and new strategic shipping alliances), Kaohsiung Port authority must accelerate the upgrade of its container terminals, integrate its port resources to build deep-water berth facilities with highefficient container operating system, and improve the operating efficiency of its existing terminals, as a means to maintain the status of Kaohsiung Port as a regional centre.

\section{NOMENCLATURE}

$\begin{array}{ll}d_{i} & \text { Obtain the sum of each column } \\ L & \text { Limited Super Matrix L } \\ r_{i} & \text { Obtain the sum of each row } \\ T & \text { Direction-Relation Matrix } \\ T_{d}^{a} & \text { Each criterion tij of Influence Matrix } \\ W^{a} & \text { Multiply T } \mathrm{D}_{\mathrm{a}}^{\mathrm{a}} \text { by W to obtain the } \\ & \text { weighted Supermatrix W } \\ \text { ANP } & \text { Analytic Network Process } \\ \text { DANP } & \text { Decision Analytic Network Process } \\ \text { DEMATEL } & \text { Decision Making Trial and Evaluation } \\ & \text { Laboratory } \\ \text { MCDM } & \text { Multiple Criteria Decision Making } \\ \text { MPA } & \text { Maritime and Port Authority of } \\ & \text { Singapore } \\ \text { TIPC } & \text { Taiwan International Ports Co., Ltd. } \\ \text { UNCATD } & \text { United Nations Conference on Trade } \\ & \text { and Development }\end{array}$

\section{INTRODUCTION}

In addition to being a country's gateway for the transportation of international cargo, ports are a crucial indicator of a country's urban development and commercial transactions. Economic globalization has increased the demand for cargo transportation, and vessels have continually been made larger as a result. However, port facilities must be continually upgraded to accommodate these vessels of increasing size. In particular, traditional hub ports, such as those of Shanghai, Singapore, Hong Kong, Kaohsiung, Tanjung Pelepas and Busan, have had to constantly modernize their equipment, expand or construct deep-water ports, and provide subsidy policies to improve their competitiveness ( $\mathrm{Su}$ et al., 2016). These measures are especially necessary if their standing as hub ports is to be maintained. However, as dedicated land for ports is limited, ports must compete for land with coastal cities for augmenting their competitive edge. If urban development or external environmental factors affect port competitiveness, the government must plan ahead to expand, relocate, or re-plan the port-all of which entail replacing the old terminal and switching terminal capacity.

Ports must engage in land reclamation and conduct terminal resettlement to remain competitive, especially in the context of vessel upsizing and the consolidation and alliance in the global shipping industry. In particular, despite their similarity of having intrinsic geographical advantages, the Port of Shanghai and Port of Singapore have adopted different policies and guidelines. Specifically, the port management policy in China adopted at the Third Session of the Standing Committee of the Tenth National People's Congress of the People's Republic of China on June 28, 2003. They were amended for the first time in accordance with the Decision on Amending the Law of the People's Republic of China on Ports, which stipulates a "one port, one government, and Separate Government Functions from Enterprise Management" principle government, and that commercial operations are to be distinguished, but ports are to coordinate their operations under the protocol. The Chinese government has adopted mandatory measures governing terminal capacity transfer. For example, terminals in the Port of Shanghai are clearly segmented into different operating areas by shipping route operations serving the Asia-Mediterranean; Trans-Pacific routes are concentrated in the Waigaoqiao port area; those serving the route to Far-Europe are concentrated at the Yangshan port area. Although container carriers were inconvenienced when these measures were first adopted, the Port of Shanghai has consecutively been ranked as the world's largest container operation port due to its strategic location and vast hinterland. 
Similarly, although Singapore has inherent geographical advantages, which are sufficient for the Port of Singapore to evolve into a regional transshipment center, Singapore's limited landmass and non-existent hinterland remain impediments. With vessel upsizing and the consolidation and alliance in the global shipping industry, the Singapore government began formulating plans in 2013 to reclaim land for terminal expansion. The operational volume of containers from the urban terminals of Tanjong Pagar, Keppel, Brani, and Pasir Panjang will be gradually diverted to Tuas Terminal in the west of Singapore over four stages within 30 years, According to PSA International, Tuas Terminal has a proposed handling capacity of 65 million TEU annually, and it has a super terminal that can accommodate vessels over 400 $\mathrm{m}$. This proposed terminal has been undergoing development according to plans by the Maritime and Port Authority of Singapore. With these developments, Singapore is expected to defend its leading position in the world's transportation industry, where competition among ports is fierce.

Regarding operations of landlord ports, the Port of Hong Kong and the Port of Kaohsiung, which outsource their terminals to private corporations or carriers, have experienced a marked decline in their operational volumes due to the emergence of vast ports in mainland China. The respective governments overseeing these ports have taken the lead in planning, adopted the policy of terminal reengineering, and increased capacity transfer in order to make their ports more competitive. As a result of being affected by this dynamic external environment, the throughput of Hong Kong ports has gradually declined in recent years, while the throughput of Kaohsiung Port has only increased slightly. Based on the statistics of ALPHALINER Monthly Monitor (2020), the throughput of Hong Kong port dropped by $6.3 \%$ in 2019 , while the throughput of Kaohsiung Port remained stable. In the case of Hong Kong, the government has assisted container terminal operators in solving the problem of berth dispersion, where existing terminals have thus been dredged to ensure the smooth entry and exit of large vessels. Such measures are founded on the premise of noninterference with market competition (Qiang et al., 2017). However, the feasibility of port consolidation and the development of new terminals is still being assessed. Regarding the Port of Kaohsiung, although most of its terminals are for dedicated use, they face similar challenges of berth dispersion and terminal consolidation. Therefore, policymakers for both ports must devise a practical and feasible consolidation plan that addresses how terminals with the same function can be consolidated, and how the port can be expanded in accordance with industrial and market demands. Furthermore, authorities must comprehensively analyze the benefits of capacity transfer scenarios when planning the terminal handling capacity of these ports.

The Port of Kaohsiung is the largest container port in Taiwan. Due to various challenges, such as vessel upsizing, insufficient water depth in the port, and insufficient terminal length, the existing six container centers have recently been unable to accommodate mega container vessels in the port area. Additionally, due to the problems of berth dispersion and terminal consolidation, many larger container carriers have withdrawn their trunk routes from the Port of Kaohsiung, resulting in stagnation in the port's operational volume growth (Tai et al., 2014). With government backing, a 7th container center has been developed in the outer harbor area of the second terminal. Five new deep-water container berths with a total length of $2415 \mathrm{~m}$ and a water depth of $18 \mathrm{~m}$ have been constructed to simultaneously accommodate five $22,000 \mathrm{TEU}$ mega container vessels for berth handling. These terminals are expected to be completed by 2023 . The Port of Kaohsiung must transfer or redirect the terminal capacity of the old container center to other deep-water terminals in the future. This will be necessary to meet the requirements resulting from the trend toward mega vessels and to solve potential conflicts among the port's existing terminal operators. Based on the terminal operator's perspective, this study summarizes the primary factors influencing the location transfer of the Port of Kaohsiung's container terminal, and based on these factors, policymakers can better maintain the port's existing advantages and status as a hub port.

\section{LITERATURE ON CONTAINER TRANSPORTATION DEVELOPMENT}

\subsection{GLOBAL PORT AND TRANSPORTATION MARKET DEVELOPMENT}

Contemporary ports can be distinguished into three types: mega-hub ports, regional hub ports, and feeder ports (Hsu and Hsieh, 2005). Large container carriers tend to have complex and diverse operational demands, particularly in berthing conditions and port selection. Thus, when allocating trunk routes, they consider factors such as the port's equipment and external environment, as well as the policy incentives from using the port (Tai and Hwang, 2005; Kadaifci et al., 2018). Regarding port selection, operators consider characteristics, such as terminal hardware facilities, channel, terminal length, water depth, cargo sources, and the presence of a hinterland. Terminal operators and the government have either constantly upgraded the port's equipment and shore handling machines or constructed more terminals to both attract carriers and meet the requirements of ever-evolving mega vessels. These measures are aimed at getting mother vessels to refer to the port as their port of call, which better allows the port to get upgraded to a large hub port. Therefore, a superior geographical location is hardly the pivotal factor in port competitiveness (MOTC, 2016; Tai and Yang, 2016; Vega et al., 2019).

Container carriers have adopted operational strategies, such as alliances, mergers, and acquisitions, and vessel upsizing, to reduce unit costs and pursue cost benefits (CNSS, 2017; Park and Suh, 2019). At present, to enhance their market competitiveness, carriers have 
developed vessels capable of loading more than 22,000 TEU, reaching the maximum limit for the Strait of Malacca and the Suez Canal (Lai and Lee, 2018; Wang, 2016). According to the latest statistics from the United Nations Conference on Trade and Development (2019) and the ALPHALINER (2019), large container vessels greater than 10,000 TEU constitute more than $36 \%$ of the vessels in the global container fleet. Members of shipping alliances cooperate on routes to expand the market, reduce marine unit transportation costs, and improve the utilization rate of shipping space. Additionally, through such cooperation, they are able to reduce crew expenses, insurance expenses, port operation fees, and fuel costs per unit TEU, thereby achieving economies of scale (Yap and Zahraei, 2018). To adapt to mega vessel trends, port facility upgrades must be timely. Furthermore, the warehousing and logistics infrastructure must be upgraded accordingly to attract customers (Hsu and Hsieh, 2005). Since major container carriers worldwide function across a network of transoceanic routes, they deploy trunk routes and cargo collection routes at hub ports to facilitate container transshipment (Lin and Tai, 2016; Kavirathna et al., 2018). Notable developments in the maritime market, such as changes in the global port operating environment, manufacturing production bases shifting gradually from mainland China to Southeast Asia, the restructuring of strategic alliances between container carriers, the widening of the Panama Canal, the potential impact of terminal location competition, cooperation in the port area, and the development of new routes, directly influence the routing and fleet deployment of liner carriers in the Port of Kaohsiung, as well as the operation and management of the port management unit (Hsu and Hsieh, 2005). With the development of new channel and the expansion of the Panama Canal, the Port of Kaohsiung has had problems relating to facilities, operation, resource integration, and energy protection. In the short term, the port must accommodate upsized vessels and adapt to the operating behavior of newly formed strategic alliances between container carriers. Over the long term, the widening of the Panama Canal has decreased the numbers of vessels operating in the US-East route and berthing in the Port of Kaohsiung (Qiang et al., 2017; MOTC, 2017a; Tai, 2016; MOTC, $2017 \mathrm{~b}$; Chen, 2019). This reduction is also because the exchange market for the transshipped containers is primarily sourced from the five major regions of the United States, mainland China, Japan, Vietnam, and the Philippines, which have not changed in the past 8 years (Tai, 2015; Tai and Yang, 2017). However, with the construction and operation of numerous container terminals in neighboring deep-water ports in southern China and Southeast Asia, transshipment routes around the Port of Kaohsiung for mother vessels and feeder vessels of major container carriers in East Asia have undergone significant structural changes. These changes are due to these vessels' dependence on the transshipment market. Furthermore, these changes have, in turn, decreased the US market's transshipment ratio, which had been the largest source of transshipment containers for many years (Hsu and Hsieh, 2005; Tai, 2012). Therefore, the Port of Kaohsiung should reposition itself to develop the supply and engage with niche markets in regions other than those involved in the North America-Southeast Asia transshipment market (Hsu and Hsieh, 2005).

\subsection{IMPACT OF UPSIZING SHIPS ON KAOHSIUNG PORT}

Tai (MOTC, 2017a) noted many key implications of the dedicated terminal system for container carriers in the Port of Kaohsiung for the container terminal industry. That study also discussed coping strategies, such as policy support, the stimulation of market demand, the offsetting of operating costs, and improvements to the operating environment. These factors are the most relevant to the different container terminals with sustainable and tandem growth in the same port. Considering the key factors that affect the relocation of terminal operators in the fourth container center of the Port of Kaohsiung, Kang (MOTC, 2017a ; MOCT, 2017b) proposed that reform for the port is most likely to involve the operating conditions of the terminal, the cost structure of the container yard, the connection of inland transportation, and the government's strategic planning for the container terminals in Taiwan. At present, the trend toward mega vessels is affecting operations at the Port of Kaohsiung's terminals. Each terminal has different facilities and equipment, and the water depth in the port area is inadequate. Only the terminals of the fourth and sixth container centers can cater to operations involving large container vessels. Policymakers should actively promote the construction of Intercontinental Container Terminal Project Phase II (the $7^{\text {th }}$ container center), and upgrade the operating machinery in the port area to meet the demands of large vessels (Tai and Tsai, 2019). Regarding the environment, deep-water terminals are increasingly required because of competition with neighboring ports and changes in the container carrier market from either mergers and acquisitions or alliance restructuring (Tai and Tsai, 2019b).

Due to the slow progress of terminal expansion and the continual withdrawal of large container carriers from terminal operations, policymakers must integrate the existing terminal operators leasing the old port area, replace the old port area with a new offshore port area, and promote the redevelopment of the port area. The port management unit must also formulate policy incentives and subsidies, as well as devise safety operation specifications for the traffic flow control and sequencing of large vessels transiting through the port. Additionally, they must prepare tugboats with adequate horsepower and an adequate quantity of tugboats to meet the needs of mega container vessels and large petrochemical liquid bulk carriers entering and leaving the ports in order to maintain navigation safety and port efficiency (Xu et al., 2015). Moreover, policymakers must take various measures for the Port of Kaohsiung to regain its status as a hub port, 
specifically through developing the port area's hinterland, improving external transportation, investing in ports, upgrading the quantity and quality of equipment, and introducing alternative handling operation systems to meet the requirements of container carriers adopting the port as their home port (MOST, 2017; Tsai and Tai, 2019b; Davidson, 2016). These potential influences on changes to the operations of major terminal operators in the container port are summarized in Table 1.

\section{PLANNING FOR CAPACITY TRANSFER SCENARIOS OF CONTAINER TERMINALS}

\subsection{FACTORS PERTAINING TO NEW AND OLD CONTAINER TERMINALS IN THE SAME PORT AREA}

The management and operation of ports are mostly implemented using the landlord port model or similar models. With the development of ports and the shifts in environmental demands, capacity transfer between old and new terminals is generated in the same port area against the backdrop of ecological demands, the economy, and the transportation market. The Port of Singapore, Hong Kong, Tanjung Pelepas, Shanghai, Xiamen, and Fuzhou all face similar challenges. The factors leading to capacity transfer are as follows:

1. Port and city: Along with the urban expansion, incompatibilities between ports and their adjacent cities have emerged. The conflict of land use is severe in old port areas. Therefore, the relationship between ports and cities has also changed accordingly. According to
Holye's (1989) ports and cities are interrelated and where cities depend on ports for development. With the advent of the commercial era, cities must continually develop, and ports must continually improve and upgrade their functions because of ecological factors. Ports then gradually become separated from cities and even get relocated away from urban areas, and the government redevelops the waterfront areas where old port facilities were based. For example, the Port Authority of Singapore leased three urban terminals from the government during the beginning of port development. With the lease expiring in 2027, the government and terminal operator are expected to transfer all container terminal capacity to Tuas Terminal at the west of Singapore, and the old urban coastal terminals might be developed by the government to meet the demand for hydrophilic recreation, thereby achieving the diversified reconstruction of the port.

2. Port infrastructure and equipment: All ports should keep pace with the upsizing of container vessels. They should be able to accommodate large vessels to maintain their competitiveness and retain their status as a hub port. Terminal facilities and machinery must be updated; port channel must be deepened, and the hinterland must be expanded to enhance port capacity (Chao et al., 2018).

3. Land for port use is becoming increasingly scarce as the city develops, making it challenging to plan and construct traffic routes. With port functions gradually being upgraded from loading/unloading and transportation to the high value-added functions had by free trade ports such as logistics and deep processing the demand for transportation routes connecting the port with adjacent cities has become increasingly important.

Table 1: Factors affecting the swift of container terminals based on previous studies

Important Dimensions and condition

Literature

A. Overall planning of the container port:

1. sustainable operation

2.overall planning direction of the port area

B. operation conditions of terminals: attraction for suitable vessel types and routes.

C. Cost input of the terminal operators:

1.various yard machines.

2.terminals operation cost.

D. External transportation connection of the port:

1.transportation convenience.

2.terminal location
Davidson (2016), Tai and Yang (2016), Su et al.(2016), Tai (2017b, 2018), Kadaifci et al. (2018), Lai and Lee (2018), Yap and Zahraei (2018), Tai and Tsai (2019b)

Davidson (2016), UNCTAD (2018), Tai and Yang (2016), Tai (2016, 2018), Kang (2019), Wu (2016), Chen (2019), Chen et al. (2015), MOTC (2015, 2017a, 2017b), Kavirathna et al. (2018), Kadaifci et al. (2018)

Gomez Paz et al,. (2015), Wang and Cheng (2015), MOCT (2013), Yang et al. (2014), Qiang et al. (2017), Chao et al. (2018), Tai and Tsai (2019), Park and Suh (2019)

MOTC (2013, 2015, 2016, 2017a, 2017b), Tai (2016), Kadaifci et al. (2018) and Vega et al. (2019) 
4. The strategic alliance between container shipping carriers can provide more diversified transportation services. This alliance can not only achieve economies of scale but also create value by reducing unit costs and increasing profits (Kim, 1998). If the alliance is restructured, the carriers will be affected by the interaction between the affiliated carriers with regard to port selection, and changes in routing deployment will also affect the competitive situation between ports and carriers. Considering the market environment, such restructuring may not affect the routing deployment behavior between alliances, and this consequently affects the willingness of container carriers to continue leasing dedicated terminals.

5. Integrating same-function terminals to enhance the demand for the industrial agglomeration effect and reduce container terminals are in competition with each other. As exemplified by the Port of Kaohsiung, existing petrochemical zones, fishing ports, container terminals, and other areas are often blocked from each other. Consequently, terminals with the same functions cannot be coherently configured, the rear line configuration of terminals cannot be more effectively used, and the route between ports must cross urban roads, thus reducing operational cost efficiency and increasing each terminal's operating costs.

\subsection{THE PORT OF KAOHSIUNG - A CASE STUDY}

The Port of Kaohsiung is the largest international commercial port and the largest container port in Taiwan. Currently, the port has six container centers and 27 wharves. The location of each container terminal is shown in Figure 1 and Table 2. Most of the dedicated terminals are owned by carriers, while a few terminals are leased to the terminal operating and handling companies, and TIPC self-manages two container berths. In addition to operating import and export containers, these terminals also increasingly attract transshipment container sources (Chen, 2019). The primary container source in the Port of Kaohsiung is through transit or transshipment, which comprises approximately half of the total container volume (Tai, 2015; Chen, 2019; MOTC, 2017a ; MOTC, 2017b).

MOTC (2017a and 2017b) noted many key implications of the dedicated terminal system for the container carriers and the container terminal industry in the Port of Kaohsiung. That study also discussed coping strategies, such as policy support, the stimulation of market demand, the offsetting of operating costs, and improvements to the operating environment. These factors are the most relevant to the different container terminals with sustainable and tandem growth in the same port. Due to the possible impact of the alliance restructuring and mergers and acquisitions among global container carriers on the demand for container terminals in Taiwan, $\mathrm{Wu}$ (2016) argued that the construction of the Intercontinental
Container Terminal Project Phase II (the 7th container center) should proceed in response to the global transportation revolution and the fast-emerging trend toward mega vessels. He proposed that to meet the needs from developments in international logistics, Taiwan must expand the port's base of operations and logistics hinterland to attract investment from international manufacturers and large logistics operators; the design should also be consistent with the increase in port operation volume and overall trends in operational development. Upon its commissioning, the 7 th container center will have a water depth of 16-18 m, and it can provide deep-water container terminals for berthing container vessels of a capacity larger than 22,000 TEU. The container center adds approximately 4.5 million TEU to the port's annual transportation capacity. In addition to the current 10 million TEU annual transportation capacity of the Port of Kaohsiung, the supply in Taiwan alone will be unable to support the projected capacity of more than 14.5 million TEU; this may induce a competitive crowding-out effect on existing terminals. Therefore, considering the promotion of future investment from the $7^{\text {th }}$ container center, policymakers must integrate the existing carriers and operators leasing the old port area, promote the redevelopment project of the port area, replace the terminals in the old port area with those in the new offshore port area, and move toward a "one terminal, one operator" model (MOCT, 2017b; Tai and Yang, 2016). As the highest-level container terminal in the Port of Kaohsiung when constructed, the 7th container center must be fully utilized, particularly given its ability to accommodate large container vessels. Thus, the port can meet the requirements of the few alliance carriers who adopt the Port of Kaohsiung as their hub port base, thereby allowing it to reclaim its status as a hub port (MOTC, 2015; Wang, 2015).

\section{RESEARCH METHODS}

This study adopts the Decision Analytic Network Process (DANP) method, it is a Multiple Criteria Decision Making (MCDM) model comprising of Analytic Network Process (ANP) theory and of the Decision Making Trial and Evaluation Laboratory (DEMATEL) method, which can not only specify the causal relationships between constructs and criteria, but also generate a weight-based ranking of constructs and criteria.

Government agencies and experts believe that the development scheme for an individual area is conducive for policy implementation and the planning of a port area. However, because the terminal operators affiliated with carriers do not have operational autonomy at the Port of Kaohsiung, the carriers' goals and overall deployment cost of routes are the primary operational criteria. In the port area, centralized planning is necessary for some issues, such as the arrangement of outbound roads and the lack of tugboats. Nonetheless, the development policies for container terminals at the Port of Kaohsiung have 
historically been focused on generating new port capacity, and thus, have neglected to develop and adapt old container terminals or container centers. Applying the DANP model helps elucidate the main factors affecting the switching of operational locations by operators of container terminals at the Port of Kaohsiung, we also determined that this approach can be appropriately applied to the case study.

First, we developed a plan concerning switching scenario for the container terminals at the Port of Kaohsiung. We then analyzed the benefits of these scenarios with respect to feasible relocation plans. Subsequently, we interviewed experts and distributed questionnaires regarding the expected benefits and obstacles after port reallocation. Finally, we determined the factors that would be considered by TIPC and terminal operators. Based on TIPC's position on the issue, their primary concern is the overall planning of the port. This is the sole criterion determining whether to switch container terminal operations, which means that the factor of inadequate depth of water at the harbor is neglected. Additionally, the TIPC cannot provide solutions for problems surrounding the carrier alliance and the perceptions of terminal operators. For terminal operators, cost, terminal operation, and outbound transportation are their primary factors of concern. Operators are ambiguous with regards to their methods of attracting carriers to berth despite their sizable financial investment in the terminal.

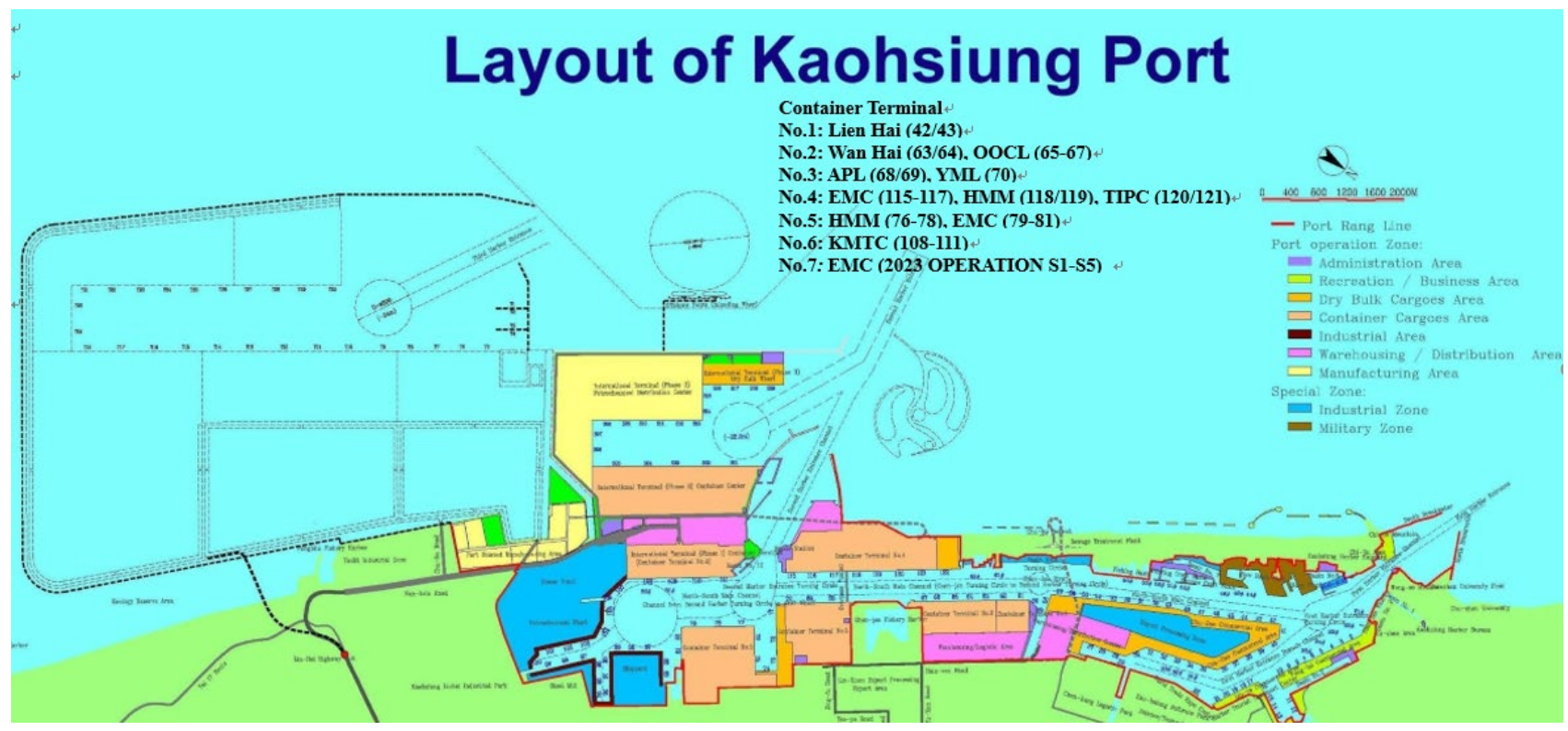

Figure 1: Layout of Kaohsiung port (Data source: TIPC, 2020)

Table 2: The characteristics and operators of the container terminals in Kaohsiung Port

\begin{tabular}{|c|c|c|c|c|}
\hline \multirow{2}{*}{ NO. } & Wharf No. & Length(m) & Designed Depth(m) & Operator \\
\hline 1 & $42-43$ & 420 & 10.5 & Lien Hai \\
\hline \multirow{2}{*}{2} & $63-64$ & 521 & 14.5 & Wan Hai \\
\cline { 2 - 5 } & $65-67$ & 760 & 14.5 & OOCL \\
\hline \multirow{3}{*}{3} & $68-69$ & 640 & 15.5 & APL \\
\cline { 2 - 5 } & 70 & 320 & 14 & YML \\
\hline \multirow{3}{*}{4} & $115-117$ & 917 & 14 & HMM \\
\cline { 2 - 5 } & $118-119$ & 640 & 14 & TIPC \\
\hline \multirow{2}{*}{5} & $120-121$ & 640 & 15 & HMM \\
\hline \multirow{2}{*}{6} & $76-78$ & 995 & 14 & EMC \\
\hline 7 & $108-111$ & 815 & 17.6 & KMTC \\
\hline
\end{tabular}

Data source: TIPC (2020). 
After collating findings from the literature review, switching scenarios at the Port of Kaohsiung, and expert interviews, this study conducted a survey titled "Factors Affecting Container Terminal Operators at the Port of Kaohsiung during the Switch in Operational Location." The survey results were used to construct the questionnaire framework. The questionnaire had four major constructs and 14 criteria, and the constructs and criteria were interdependent. Subsequently, a DANP questionnaire was designed based on the framework of factors and distributed to experts. A survey was conducted via questionnaires and participant interviews of 16 expert-policymakers. The detailed information of the experts is listed in Table 3. The DANP method was used to calculate weights. After the questionnaires are collected, MATLAB software and Excel software are used as the calculation tools to conduct empirical evaluations to obtain the weights and rankings of the importance of each evaluation standard affecting the container terminal operators at the Port of Kaohsiung during the factor on the switch of container terminal operation location (Table 4 ).

Table 3: Details of Interviewers for Survey

\begin{tabular}{|c|c|c|c|c|c|}
\hline & Sector & Title & & Sector & Title \\
\hline 1 & TIPC & Director & 9 & Zone 2: O. company & Labor manager \\
\hline 2 & TIPC & Manager & 10 & Zone 4: H. company & Vice President \\
\hline 3 & Scholar & Professor & 11 & Zone 4: H. company & Planer manager \\
\hline 4 & TIPC & Vice President & 12 & Zone 3: A. company & Vice President \\
\hline 5 & Scholar & Professor & 13 & Zone 3: Y. company & Planer manager \\
\hline 6 & Zone 2: W. company & Vice President & 14 & Zone 2: W. company & Vice President \\
\hline 7 & Zone 2: W. company & Operator & 15 & TIPC & Director \\
\hline 8 & Zone 2: O. company & Planer manager & 16 & TIPC & Manager \\
\hline
\end{tabular}

Table 4: Main factors affecting the switch of container terminal Important constructs

Important criteria and factors under the constructs

A The overall planning of the port: A1 Safety of the operation locations at the port

A2 Continuity of the incentive and subsidy mechanism of the port

A3 Compulsory competitive terms of the public port

A4 Entirety of the overall planning of new and old port areas

B The operation conditions of the

B1 The sufficiency of routes berthing at the terminals terminals:

B2 Limitation of ship type eligible for berthing at the terminals

B3 Appropriateness of the operation locations at the port

B4 Willingness to attract non-leasing carriers to berth

C The cost of switching:

C1 Cost of equipment

$\mathrm{C} 2$ Cost of site refinement

C3 Cost of switching intermediate containers among terminals

D The connection with inland

D1 The accessibility of outbound transportation of the container yards transportation:

D2 Attraction and operation of transshipment containers

D3 Neighboring locations of the container yards

Note: Summarized from literature review and expert interviews. 
4.1

\section{THE DEMATEL METHOD}

This study utilizes the DEMATEL to construct the influence and mutual influencing relations (Tzeng et al., 2007), where it then applies the total-influence matrix acquired from the DEMATEL method (i.e., matrix $\mathrm{T}$ in the ANP supermatrix). The steps are detailed as follows:

Step 1: Generate the direct-influence relations matrix between constructs and criteria

First, collect related criteria through methods, such as a literature review, brainstorming, and soliciting expert opinions before collating and defining the data. Subsequently, distribute questionnaires to experts to obtain the value of the mutual influence between the criteria using the five-point evaluation scheme. Specifically, 0, 1, 2, 3, and 4 indicate "no influence," "small influence," "medium influence", "large influence" and "very large influence", respectively (Lin \& Wu, 2008). In summary, list the criteria, specify the definition of the criteria through expert interviews and a literature review, and apply the five-point evaluation scheme.

\section{Step 2: Develop the direction-relation matrix $X$}

When there are $n$ criteria, the expert questionnaire is used for comparison between every two criteria with respect to the degree of their mutual influence, where an $n \times n$ direction-relation matrix is generated, which we denote as $X$. In $X, X_{i j}$ represents the degree of influence of criteria $i$ on criteria $j$, and the diagonal of the matrix is the degree of influence of each criterion on itself, which is set as 0 (i.e., no influence). Matrix $X$ can be written as:

$$
\mathrm{X}=\left[\begin{array}{cccc}
0 & x_{12} & \cdots & x_{1 n} \\
x_{21} & 0 & \cdots & x_{2 n} \\
\vdots & \vdots & \ddots & \vdots \\
x_{n 1} & x_{n 2} & \cdots & 0
\end{array}\right]
$$

Step 3: Establish the normalized direction-relation matrix $D$

Generally, there are two normalization methods. In the first method, the maximum sum of the column vector is taken as the normalized standard (Wu and Lee, 2007). In the second method, the maximum sum of either the column vector or row vector is taken as the normalized standard (Tzeng et al., 2007). This second method can prevent polarization in the subsequent calculation using the value in the matrix. Therefore, this study adopted the second method. The normalized direction-relation matrix is denoted as matrix $D ; D$ contains the normalized standard $S$, and the calculations of $D$ and $S$ are presented in Formula 1 and Formula 2, respectively as follows.

$$
\begin{aligned}
& D=S X \\
& \mathrm{~S}=\frac{1}{\max \left[\max _{1 \leq i \leq n} \sum_{j=1}^{n} x_{i j} \max _{1 \leq j \leq n} \sum_{i=1}^{n} x_{i j}\right]}
\end{aligned}
$$

Step 4: Construct the total-influence matrix $T$

After obtaining matrix $D$, Formula 3 is used to transpose the total-influence matrix, among which $I$ is the unit matrix.

$\mathrm{T}=\lim _{\mathrm{k} \rightarrow \infty}\left(D+D^{2}+\cdots+D^{k}\right)^{\mathrm{n}}=D(I-D)^{-1}$

Step 5: Calculate the total-influence matrix map

Calculate the sum for each row and column of the totalinfluence matrix; then obtain the sum of each row, $d_{i}$ and the sum of each column, $r_{j}$. The calculations are shown in Formula 4 and Formula 5 as:

$$
\begin{aligned}
& d_{i}=\sum_{i=1}^{n} t_{1 j}(j=1,2,3 \cdots n) \\
& r_{i}=\sum_{j=1}^{n} t_{1 j}(i=1,2,3 \cdots n)
\end{aligned}
$$

Step 6: Calculate the prominence $\left(d_{i}+r_{j}\right)$ and relation $\left(d_{i}-r_{j}\right)$

Then calculate $d_{i}+r_{j}$ and $d_{i}-r_{j}$ according to formulas (4) and (5). When $\mathrm{i}=\mathrm{j}$ and $\mathrm{i}, \mathrm{j} \in\{1,2, \ldots, n\}$. The horizontal axis vector $\left(d_{i}+r_{i}\right)$ provides an index is call the "prominence" illustrates the strength of influences that are given and received of the factor, that is, $\left(d_{i}+r_{i}\right)$ shows the degree of the central role that criterion i plays in the problem. Similary, the vertical axis vector $\left(d_{i}-r_{i}\right)$ called "Relation". If $\left(d_{i}-r_{i}\right)$ is positive, A positive relation value suggests that the criterion in question falls under the category of cause indicators; otherwise, the criterion in question belongs to the category of effect indicators(Liou et al., 2007).

\section{Step 7: Chart the causal diagram}

The causal diagram is divided into four quadrants by two lines, which represent the mean of the lateral axis $\left(d_{i}+r_{j}\right)$ and the mean of the vertical axis $\left(d_{i}-r_{j}\right)$. The quadrants encompass all criteria in the diagram, and their use streamlines descriptions of complicated causal patterns. The quadrants facilitate analyses on the relation and prominence degree of each criterion. Figure 2 describes the implications of the quadrants. 


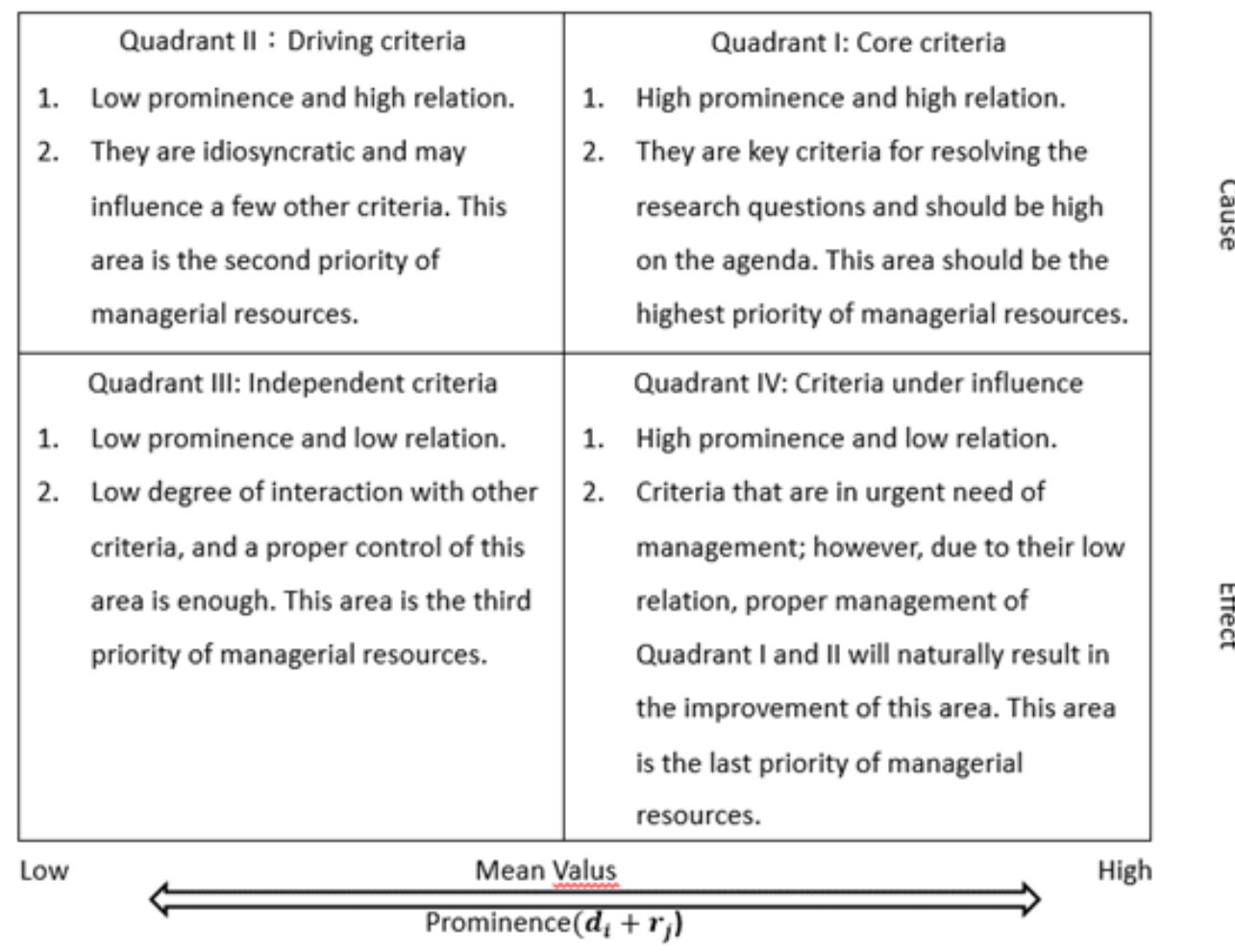

Figure 2: Implications of the Four Quadrants of the DEMATh
4.2 COMBINED DEMATEL + ANP METHOD
FOR OBTAINING CRITERIA WEIGHTS

The ANP, as presented by Saaty in 1999, was used to adapt to the decision-making method of the non-independent hierarchical structure. Ou Yang et al. (2008) revealed that in the calculation of the ANP supermatrix, the normalization method carries the assumption that every cluster exerts the same degree of influence, hence, it adopts the equally weighted method to obtain the weighted supermatrix. Although this approach is relatively simple, it cannot be applied when different clusters should have different degrees of influence. Thus, their study proposed the approach of incorporating the DEMATEL and ANP to make the calculated ANP supermatrix applicable to clusters with different degrees of influence. The steps of the DANP method are detailed as follows:

Step 1: Normalize the total-influence matrix $T$ and transpose it into the unweighted supermatrix $W$

First, take matrix $T$ (Formula 6) and normalize it (Formula 7) to obtain the normalized total-influence matrix, $T_{1}$ among which $d_{1}$ (Formula 8 ) is the sum of the column values of $T$.

$T=\left[\begin{array}{ccccc}t_{11} & \cdots & t_{1 j} & \cdots & t_{1 m} \\ \vdots & & \vdots & & \vdots \\ t_{i 1} & \cdots & t_{i j} & \ldots & t_{i m} \\ \vdots & & \vdots & & \vdots \\ t_{m 1} & \cdots & t_{m j} & \ldots & t_{m m}\end{array}\right]$

$$
\begin{aligned}
& T_{1}=\left[\begin{array}{ccccc}
t_{11} / d_{1} & \ldots & t_{1 j} / d_{1} & \ldots & t_{1 m} / d_{1} \\
\vdots & & \vdots & & \vdots \\
t_{i 1} / d_{1} & \ldots & t_{i j} / d_{1} & \ldots & t_{i m} / d_{i} \\
\vdots & & \vdots & & \vdots \\
t_{m 1} / d_{m} & \ldots & t_{m j} / d_{m} & \ldots & t_{m m} / d_{m}
\end{array}\right] \\
&=\left[\begin{array}{ccccc}
t_{11}^{1} & \ldots & t_{1 j}^{1} & \ldots & t_{1 m}^{1} \\
\vdots & & \vdots & & \vdots \\
t_{i 1}^{1} & \ldots & t_{i j}^{1} & \ldots & t_{i m}^{1} \\
\vdots & & \vdots & & \vdots \\
t_{m 1}^{1} & \ldots & t_{m j}^{a n j} & \ldots & t_{m m}^{a n n}
\end{array}\right]
\end{aligned}
$$

$d_{i}=\sum_{j=1}^{n} t_{i j}$

Subsequently, take $T 1$ and fill in its values according to the interdependent relations between criteria. With these values substituted, $T 1$ becomes the unweighted supermatrix $W$, as written in Formula 9:

$\mathrm{W}=\left[\begin{array}{cccc}w_{11} & w_{12} & \ldots & w_{1 n} \\ w_{21} & w_{22} & \ldots & w_{2 n} \\ \vdots & \vdots & \ddots & \vdots \\ w_{n 1} & w_{n 2} & \ldots & w_{n n}\end{array}\right]$

Step 2: Determine the weighted supermatrix

Normalize $T_{D}$, the total-influence matrix for the constructs as a whole (Formula 10), through Formula 11 to obtain matrix $T_{D}^{a}$. Subsequently, multiply $T_{D}^{a}$ by $W$ to obtain the weighted supermatrix $W^{a}$ (Formula 12), where the sum of any row vector of $W^{a}$ is 1 . 
$T_{D}==\left[\begin{array}{ccccc}t_{D}^{11} & \ldots & t_{D}^{1 J} & \ldots & t_{D}^{1 n} \\ \vdots & & \vdots & & \vdots \\ t_{D}^{i 1} & \ldots & t_{D}^{i j} & \ldots & t_{D}^{i n} \\ \vdots & & \vdots & & \vdots \\ t_{D}^{n 1} & \ldots & t_{D}^{n j} & \ldots & t_{D}^{n n}\end{array}\right]$

$T_{D}^{a}=\left[\begin{array}{ccccc}t_{D}^{11} / d_{1} & \ldots & t_{D}^{1 j} / d_{1} & \ldots & t_{D}^{1 n} / d_{1} \\ \vdots & & \vdots & & \vdots \\ t_{D}^{i 1} / d_{i} & \ldots & t_{D}^{i j} / d_{i} & \ldots & t_{D}^{i n} / d_{i} \\ \vdots & & \vdots & & \vdots \\ t_{D}^{n 1} / d_{n} & \ldots & t_{D}^{n j} / d_{n} & \ldots & t_{D}^{n n} / d_{n}\end{array}\right]$
$=\left[\begin{array}{ccccc}t_{D}^{a 11} & \ldots & t_{D}^{a 1 j} & \ldots & t_{D}^{a 1 n} \\ \vdots & & \vdots & & \vdots \\ t_{D}^{a i 1} & \ldots & t_{D}^{a i j} & \ldots & t_{D}^{\text {ain }} \\ \vdots & & \vdots & & \vdots \\ t_{D}^{\text {an1 }} & \ldots & t_{D}^{\text {anj }} & \ldots & t_{D}^{\text {ann }}\end{array}\right]$

$W^{a}=T_{D}^{a} W$

$=\left[\begin{array}{ccccc}t_{D}^{a 11} \times W^{11} & \ldots & t_{D}^{a 1 j} \times W^{i 1} & \ldots & t_{D}^{a 1 n} \times W^{11} \\ \vdots & & \vdots & & \vdots \\ t_{D}^{a i 1} \times W^{1 j} & \ldots & t_{D}^{a i j} \times W^{i j} & \ldots & t_{D}^{a i n} \times W^{n j} \\ \vdots & & \vdots & & \vdots \\ t_{D}^{a n 1} \times W^{1 n} & \ldots & t_{D}^{a n j} \times W^{i n} & \ldots & t_{D}^{a n n} \times W^{n n}\end{array}\right]$

The normalization of the total-influence matrix for the constructs as a whole requires transposition, and the transposed value's relative position is used for weighted calculation. These are necessary to obtain the weighted supermatrix - where the sum of any row vector is 1 .

Step 3: Calculate the influential weights with the limited supermatrix.

Multiply the weighted supermatrix $\left(W^{a}\right)$ by itself several times until a convergent and stable extremum is obtained. Use this approach to calculate the criteria weights, as described in Formula 13. The limited supermatrix is denoted $L$, among which $W^{a}$ is the weighted supermatrix, and $z$ is how many times the multiplication is conducted.

$L=\lim _{\mathrm{z} \rightarrow \infty}\left(W^{a}\right)^{z}$

As evident in the aforementioned ANP rules and procedures, first, the inter-criteria weights and interdependent relations between the criteria are calculated; second, the interdependent relations between various schemes are calculated; and finally, the suitable scheme is chosen based on the weights. As most factors or criteria are interdependent in the whole process, this study adopted the aforementioned ANP method to further explore the primary factors affecting container terminal operators at the Port of Kaohsiung when operational locations are switched.

\section{DANP SURVEY AND RESULTS}

\subsection{ANALYSIS OF DESCRIPTIVE STATISTICS}

Since the switching scenarios of the port area involve various parties, such as governments, land developers, and terminal operators, interested parties must overcome a variety of challenges, and respond to an environment that is ever-evolving, increasingly competitive, and increasingly complicated; this ensures container terminal capacity upgrading, and promotes the port city's ability to remain economically vital. After related planning and influence analyses, relevant items were used to form a questionnaire utilizing a $0-4$ scale (0: "no influence," 1 : "small influence," 2: "medium influence," 3: "large influence," 4: "very large influence"). This questionnaire was used to evaluate the degree of interaction between facets and criteria.

In March 2019, the study collated the recovered DANP questionnaires from 11 experts with more than 20-25 years of experience working at container terminals of Kaohsiung port, adopted the DEMATEL method to identify the influencing relations between constructs and criteria as well as their means, and obtained the direction-influence matrix and total-influence matrix for the constructs. As previously shown in Step 1 through Step 6, we calculated the value of the rows and columns of the total-influence matrix for the constructs to obtain the prominence $\left(d_{i}+r_{i}\right)$ and relation $\left(d_{i}-r_{i}\right)$ of the sum of the columns $\left(d_{i}\right)$ and rows $\left(r_{i}\right)$.

Table 5 presents the prominence and relation of constructs. Construct A "The overall planning of the port" had the highest (7.4492) prominence, suggesting that this construct is essential relative to the main factors affecting the switching of operation locations by container terminal operators at the Port of Kaohsiung. The government bears responsibility for such overall port planning regarding shipping and port administration. Thus, the government should prioritize improvements to port planning. Regarding relation, Construct A and Construct D ("The connection with inland transportation") had values $>0$, suggesting that these two constructs belong to the cause cluster. By contrast, Construct B "The operation conditions of the terminals" and Construct C "The cost of switching" had relation values $<0$, suggesting that these two constructs belong to the effect cluster. Hence, operators should invest in the aspects covered by Constructs A and D, which directly affect the operation conditions of the terminals and the cost of switching. 
Table 5: Prominence and relation of constructs

\begin{tabular}{cccccccc}
\hline \multirow{2}{*}{ Construct code } & \multirow{2}{*}{$d_{i}$} & $r_{i}$ & $\begin{array}{c}\text { Prominence } \\
d_{i}+r_{i}\end{array}$ & \multicolumn{2}{c}{ Relation } \\
$d_{i}-r_{i}$ & \multirow{2}{*}{ Cluster } \\
\hline A & 4.6562 & 2.793 & 7.4492 & 1 & 1.8631 & 1 & Cause cluster \\
B & 3.4225 & 3.7899 & 7.2124 & 2 & -0.3674 & 3 & Effect cluster \\
C & 2.3035 & 4.1151 & 6.4186 & 4 & -1.8116 & 4 & Effect cluster \\
D & 3.4586 & 3.1427 & 6.6014 & 3 & 0.3159 & 2 & Cause cluster \\
\hline
\end{tabular}

Table 6: Total-influence matrix of criteria

\begin{tabular}{|c|c|c|c|c|c|c|c|c|c|c|c|c|c|c|c|c|c|c|c|c|c|}
\hline \multirow[b]{2}{*}{$\mathrm{A} 1$} & \multirow{2}{*}{$\begin{array}{c}\mathrm{A} 1 \\
0.15\end{array}$} & \multirow{2}{*}{$\frac{\mathrm{A} 2}{0.06}$} & \multirow{2}{*}{$\frac{\mathrm{A} 3}{0.06}$} & \multirow{2}{*}{$\frac{\mathrm{A} 4}{0.20}$} & \multirow{2}{*}{$\begin{array}{c}\mathrm{B} 1 \\
0.11\end{array}$} & \multirow{2}{*}{$\frac{\mathrm{B} 2}{0.25}$} & \multirow{2}{*}{$\frac{\mathrm{B} 3}{0.27}$} & \multirow{2}{*}{$\begin{array}{c}\text { B4 } \\
0.17\end{array}$} & \multirow{2}{*}{$\begin{array}{c}\mathrm{C} 1 \\
0.07\end{array}$} & \multirow{2}{*}{$\frac{\mathrm{C} 2}{0.05}$} & \multirow{2}{*}{$\frac{\mathrm{C} 3}{0.13}$} & \multirow{2}{*}{$\begin{array}{c}\mathrm{D} 1 \\
0.17\end{array}$} & \multirow{2}{*}{$\begin{array}{c}\mathrm{D} 2 \\
0.16\end{array}$} & \multirow{2}{*}{$\frac{\mathrm{D} 3}{0.21}$} & \multirow{2}{*}{$\frac{d_{i}}{2.05}$} & \multirow{2}{*}{$\frac{r_{i}}{2.71}$} & \multicolumn{2}{|c|}{$\begin{array}{c}\text { Prominence } \\
d_{i}+r_{i}\end{array}$} & \multicolumn{2}{|c|}{$\begin{array}{c}\text { Relation } \\
d_{i}-r_{i}\end{array}$} & \multirow{2}{*}{$\begin{array}{c}\text { Cluster } \\
\text { Effect cluster }\end{array}$} \\
\hline & & & & & & & & & & & & & & & & & 4.76 & 6 & -0.66 & 12 & \\
\hline $\mathrm{A} 2$ & 0.06 & 0.04 & 0.03 & 0.04 & 0.10 & 0.09 & 0.06 & 0.08 & 0.06 & 0.02 & 0.08 & 0.05 & 0.12 & 0.06 & 0.85 & 1.34 & 2.19 & 14 & -0.49 & 10 & Effect cluster \\
\hline $\mathrm{A} 3$ & 0.07 & 0.07 & 0.04 & 0.09 & 0.08 & 0.10 & 0.12 & 0.15 & 0.03 & 0.02 & 0.12 & 0.06 & 0.11 & 0.08 & 1.15 & 1.29 & 2.43 & 13 & -0.14 & 6 & Effect cluster \\
\hline A4 & 0.26 & 0.11 & 0.08 & 0.14 & 0.13 & 0.26 & 0.28 & 0.19 & 0.11 & 0.08 & 0.19 & 0.20 & 0.21 & 0.24 & 2.47 & 2.24 & 4.70 & 7 & 0.23 & 5 & Cause cluster \\
\hline B1 & 0.25 & 0.13 & 0.13 & 0.16 & 0.09 & 0.21 & 0.24 & 0.19 & 0.06 & 0.04 & 0.16 & 0.19 & 0.23 & 0.26 & 2.34 & 1.69 & 4.02 & 10 & 0.65 & 2 & Cause cluster \\
\hline B2 & 0.23 & 0.10 & 0.10 & 0.15 & 0.09 & 0.15 & 0.26 & 0.18 & 0.18 & 0.10 & 0.14 & 0.15 & 0.16 & 0.22 & 2.21 & 2.72 & 4.94 & 4 & -0.51 & 11 & Effect cluster \\
\hline B3 & 0.27 & 0.08 & 0.11 & 0.24 & 0.14 & 0.24 & 0.21 & 0.18 & 0.14 & 0.11 & 0.20 & 0.24 & 0.23 & 0.28 & 2.68 & 3.16 & 5.83 & 1 & -0.48 & 9 & Effect cluster \\
\hline B4 & 0.16 & 0.06 & 0.12 & 0.14 & 0.11 & 0.18 & 0.21 & 0.10 & 0.05 & 0.04 & 0.14 & 0.17 & 0.20 & 0.21 & 1.86 & 2.23 & 4.09 & 9 & -0.37 & 8 & Effect cluster \\
\hline $\mathrm{C} 1$ & 0.14 & 0.08 & 0.08 & 0.09 & 0.13 & 0.20 & 0.16 & 0.13 & 0.05 & 0.03 & 0.11 & 0.12 & 0.13 & 0.18 & 1.62 & 1.15 & 2.77 & 12 & 0.47 & 4 & Cause cluster \\
\hline $\mathrm{C} 2$ & 0.19 & 0.11 & 0.14 & 0.19 & 0.16 & 0.22 & 0.27 & 0.19 & 0.10 & 0.05 & 0.16 & 0.20 & 0.21 & 0.23 & 2.41 & 0.75 & 3.16 & 11 & 1.66 & 1 & Cause cluster \\
\hline $\mathrm{C} 3$ & 0.19 & 0.16 & 0.13 & 0.22 & 0.13 & 0.19 & 0.27 & 0.16 & 0.12 & 0.05 & 0.13 & 0.20 & 0.25 & 0.26 & 2.47 & 2.18 & 4.65 & 8 & -2.18 & 14 & Cause cluster \\
\hline D1 & 0.30 & 0.09 & 0.11 & 0.27 & 0.14 & 0.24 & 0.31 & 0.24 & 0.08 & 0.05 & 0.21 & 0.16 & 0.26 & 0.31 & 2.75 & 2.26 & 5.00 & 2 & 0.49 & 3 & Cause cluster \\
\hline D2 & 0.22 & 0.19 & 0.11 & 0.13 & 0.16 & 0.21 & 0.27 & 0.16 & 0.07 & 0.08 & 0.24 & 0.19 & 0.15 & 0.23 & 2.39 & 2.59 & 4.98 & 3 & -0.20 & 7 & Effect cluster \\
\hline D3 & 0.22 & 0.06 & 0.06 & 0.18 & 0.14 & 0.20 & 0.22 & 0.14 & 0.06 & 0.04 & 0.17 & 0.18 & 0.19 & 0.15 & 1.99 & 2.93 & 4.91 & 5 & -0.94 & 13 & Effect cluster \\
\hline
\end{tabular}

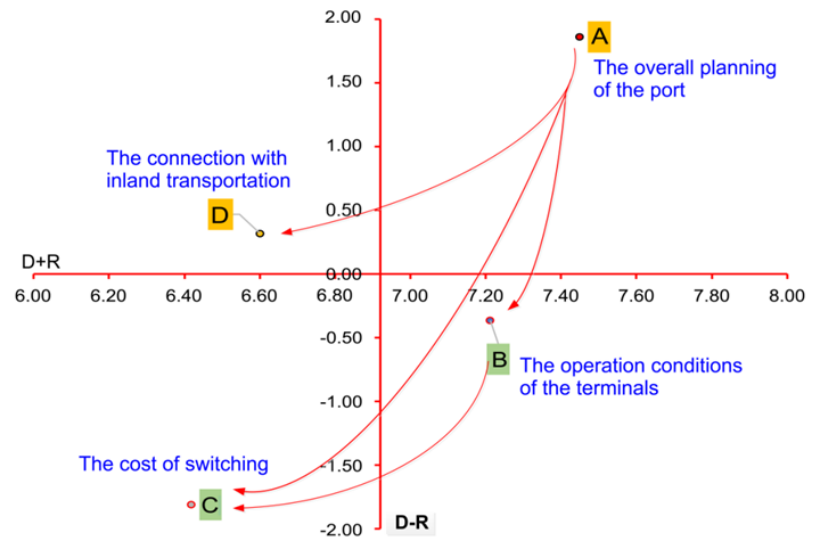

Figure 3: Causation and Correlation Analysis of the Constructs.

Based on the prominence and relation values, the coordinate $\left(\boldsymbol{d}_{\boldsymbol{i}}+\boldsymbol{r}_{\boldsymbol{i}}, \boldsymbol{d}_{\boldsymbol{i}}-\boldsymbol{r}_{\boldsymbol{i}}\right)$ is considered the paired coordinate, with the $x$ axis being $\left(\boldsymbol{d}_{\boldsymbol{i}}+\boldsymbol{r}_{\boldsymbol{i}}\right)$, and the $y$ axis being $\left(\boldsymbol{d}_{\boldsymbol{i}}-\boldsymbol{r}_{\boldsymbol{i}}\right)$. To demonstrate significant causation, the means of all construct values under the total-influence matrix are calculated and set as the threshold value for selecting the criteria; the threshold value is calculated to be 1.0315 , meaning that any value lower than 1.0315 is transformed to 0 . Figure 2 illustrates the causation of constructs, among which Construct A "The overall planning of the port" is at Quadrant I, Construct B "The operation conditions of the terminals" is at Quadrant IV, Construct C "The cost of switching" is at Quadrant III, and Construct D "The connection with inland transportation" is at Quadrant II. As illustrated in Figure 3, Constructs B, C, and D are influenced by Construct A. Therefore, any changes or improvements to Construct A will also have benefits for Constructs B, C, and D. Construct B influences improvements to Construct $\mathrm{C}$. The correlation of constructs indicates that, with respect to the main factors affecting the switching of operational locations by container terminal operators at the Port of 
Kaohsiung to shift the operation area must have a comprehensive port overall planning and outside road connection ability. it will be more conducive to the future development of the overall container transportation industry in Kaohsiung Port.

\subsection{WEIGHTS OF THE FOUR MAJOR CONSTRUCTS}

The DEMATEL method is first used to analyze the causation and correlation of constructs and criteria, and the DANP method is then used to calculate the weights of the four major constructs (A: 0.2090, B: 0.2743, C: 0.2877, and D: 0.2290). Subsequently, the correlation and causation factors of the constructs are used to calculate the total-influence matrix for the criteria. Finally, the causation of constructs and criteria are determined (Table 6).

The criteria's total-influence matrix $\mathrm{T}$ is collated to calculate the prominence and relation values. These values are then used to constitute the two-dimensional coordinates that form the causal diagram. The coordinate $\left(\boldsymbol{d}_{\boldsymbol{i}}+\boldsymbol{r}_{\boldsymbol{i}}\right),\left(\boldsymbol{d}_{\boldsymbol{i}}-\boldsymbol{r}_{\boldsymbol{i}}\right)$ serves as the paired coordinate, where the $x$ axis is $\left(\boldsymbol{d}_{\boldsymbol{i}}+\boldsymbol{r}_{\boldsymbol{i}}\right)$ and the $y$ axis is $\left(\boldsymbol{d}_{\boldsymbol{i}}-\boldsymbol{r}_{\boldsymbol{i}}\right)$. If a criterion falls above the $x$ axis, then it belongs to the "cause cluster"; otherwise, it belongs to the "effect cluster." To identify the significant influencing relations between the criteria, we set a threshold value to select criteria. Specifically, the quantile of all criteria (their mean could be used as well) is calculated, and the threshold value of 0.2007 is obtained. Thus, any criterion with a value $>0.2007$ is considered to have a significant influence, and its original value is retained; otherwise, the criterion's value is transformed to 0 . Through these steps, the threshold value is obtained, the total-influence matrix is streamlined, the influencing relations between the criteria are summarized (Table 7), and the causation and correlation analysis diagram for all criteria is generated (Figure 4).

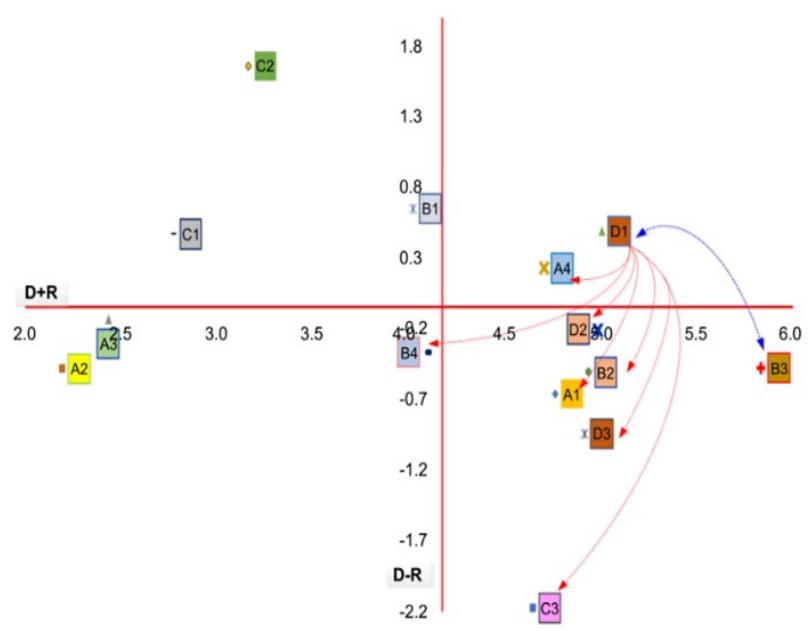

Figure 4: Causation and Correlation Analysis of Criteria (D1 as an Example).

Table 6 lists the importance of the total influence of the criteria. The most important criteria is B3 "Appropriateness of the operation locations at the port" (5.83), followed by D1 "The accessibility of outbound transportation of the container yards" (5.00). Figure 4 illustrates the criteria's causation. In Figure 4, D1 is taken as an example to illustrate the trajectory of its influence on the other eight criteria.

Table 7: Influencing relations between criteria

\begin{tabular}{|c|c|c|c|c|c|c|c|c|c|c|c|c|c|c|}
\hline \multicolumn{2}{|c|}{$\begin{array}{l}\text { Criterion } \rightarrow \\
\text { Criterion }\end{array}$} & $\begin{array}{l}\text { Influence } \\
\text { relation }\end{array}$ & \multicolumn{2}{|c|}{$\begin{array}{c}\text { Criterion } \rightarrow \\
\text { Criterion }\end{array}$} & $\begin{array}{l}\text { Influence } \\
\text { relation }\end{array}$ & \multicolumn{2}{|c|}{$\begin{array}{c}\text { Criterion } \rightarrow \\
\text { Criterion } \\
\end{array}$} & $\begin{array}{l}\text { Influence } \\
\text { relation }\end{array}$ & \multicolumn{2}{|c|}{$\begin{array}{c}\text { Criterion } \rightarrow \\
\text { Criterion }\end{array}$} & $\begin{array}{l}\text { Influence } \\
\text { relation }\end{array}$ & \multicolumn{2}{|c|}{$\begin{array}{c}\text { Criterion } \rightarrow \\
\text { Criterion }\end{array}$} & $\begin{array}{l}\text { Influence } \\
\text { relation }\end{array}$ \\
\hline \multirow[t]{3}{*}{ A1 } & B2 & Unidirectional & \multirow[t]{5}{*}{ A4 } & A1 & Bidirectional & \multirow[t]{8}{*}{ D1 } & $\mathrm{A} 1$ & Bidirectional & \multirow[t]{5}{*}{ B1 } & $\mathrm{A} 1$ & Bidirectional & \multirow[t]{7}{*}{ B3 } & $\mathrm{A} 1$ & Unidirectional \\
\hline & B3 & Unidirectional & & B2 & Bidirectional & & A4 & Bidirectional & & B2 & Bidirectional & & A4 & Unidirectional \\
\hline & D3 & Unidirectional & & B3 & Unidirectional & & B2 & Bidirectional & & B3 & Bidirectional & & B2 & Unidirectional \\
\hline \multirow[t]{4}{*}{$\mathrm{C} 2$} & B2 & Bidirectional & & D2 & Bidirectional & & B3 & Unidirectional & & D2 & Bidirectional & & $\mathrm{C} 3$ & Unidirectional \\
\hline & B3 & Bidirectional & & D3 & Bidirectional & & B4 & Bidirectional & & D3 & Bidirectional & & D1 & Unidirectional \\
\hline & D2 & Bidirectional & \multirow[t]{6}{*}{ D2 } & $\mathrm{A} 1$ & Bidirectional & & $\mathrm{C} 3$ & Bidirectional & \multirow[t]{2}{*}{ D3 } & $\mathrm{A} 1$ & Unidirectional & & D2 & Unidirectional \\
\hline & D3 & Bidirectional & & B2 & Bidirectional & & D2 & Bidirectional & & B3 & Unidirectional & & D3 & Unidirectional \\
\hline \multirow[t]{4}{*}{$\mathrm{C} 3$} & A4 & Bidirectional & & B3 & Unidirectional & & D3 & Bidirectional & \multicolumn{6}{|c|}{ Note: } \\
\hline & B3 & Unidirectional & & $\mathrm{C} 3$ & Unidirectional & \multirow[t]{3}{*}{ B2 } & A1 & Unidirectional & \multirow{3}{*}{\multicolumn{6}{|c|}{$\begin{array}{l}\text { Bidirectional means that Criterion } \mathrm{X} \text { and Criterion } \mathrm{Y} \text { influence } \\
\text { each other Unidirectional means that Criterion } \mathrm{X} \text { influences } \\
\text { Criterion Y }\end{array}$}} \\
\hline & D2 & Unidirectional & & D3 & Bidirectional & & B3 & Unidirectional & & & & & & \\
\hline & D3 & Bidirectional & & & & & D3 & Bidirectional & & & & & & \\
\hline
\end{tabular}

Note: Bidirectional means that Criterion X and Criterion Y influence each other, for e.g., D1 to B3. Unidirectional means that Criterion X influences Criterion Y, e.g., D1 to A1. 
Table 8: Criteria weights in the limit supermatrix

\begin{tabular}{ccccccccccccccc}
\hline & $\mathrm{A} 1$ & $\mathrm{~A} 2$ & $\mathrm{~A} 3$ & $\mathrm{~A} 4$ & $\mathrm{~B} 1$ & $\mathrm{~B} 2$ & $\mathrm{~B} 3$ & $\mathrm{~B} 4$ & $\mathrm{C} 1$ & $\mathrm{C} 2$ & $\mathrm{C} 3$ & $\mathrm{D} 1$ & $\mathrm{D} 2$ & $\mathrm{D} 3$ \\
\hline $\mathrm{A} 1$ & 0.093 & 0.093 & 0.093 & 0.093 & 0.093 & 0.093 & 0.093 & 0.093 & 0.093 & 0.093 & 0.093 & 0.093 & 0.093 & 0.093 \\
$\mathrm{~A} 2$ & 0.045 & 0.045 & 0.045 & 0.045 & 0.045 & 0.045 & 0.045 & 0.045 & 0.045 & 0.045 & 0.045 & 0.045 & 0.045 & 0.045 \\
$\mathrm{~A} 3$ & 0.042 & 0.042 & 0.042 & 0.042 & 0.042 & 0.042 & 0.042 & 0.042 & 0.042 & 0.042 & 0.042 & 0.042 & 0.042 & 0.042 \\
$\mathrm{~A} 4$ & 0.077 & 0.077 & 0.077 & 0.077 & 0.077 & 0.077 & 0.077 & 0.077 & 0.077 & 0.077 & 0.077 & 0.077 & 0.077 & 0.077 \\
$\mathrm{~B} 1$ & 0.058 & 0.058 & 0.058 & 0.058 & 0.058 & 0.058 & 0.058 & 0.058 & 0.058 & 0.058 & 0.058 & 0.058 & 0.058 & 0.058 \\
B2 & 0.094 & 0.094 & 0.094 & 0.094 & 0.094 & 0.094 & 0.094 & 0.094 & 0.094 & 0.094 & 0.094 & 0.094 & 0.094 & 0.094 \\
B3 & 0.108 & 0.108 & 0.108 & 0.108 & 0.108 & 0.108 & 0.108 & 0.108 & 0.108 & 0.108 & 0.108 & 0.108 & 0.108 & 0.108 \\
B4 & 0.076 & 0.076 & 0.076 & 0.076 & 0.076 & 0.076 & 0.076 & 0.076 & 0.076 & 0.076 & 0.076 & 0.076 & 0.076 & 0.076 \\
C1 & 0.04 & 0.04 & 0.04 & 0.04 & 0.04 & 0.04 & 0.04 & 0.04 & 0.04 & 0.04 & 0.04 & 0.04 & 0.04 & 0.04 \\
C2 & 0.027 & 0.027 & 0.027 & 0.027 & 0.027 & 0.027 & 0.027 & 0.027 & 0.027 & 0.027 & 0.027 & 0.027 & 0.027 & 0.027 \\
C3 & 0.076 & 0.076 & 0.076 & 0.076 & 0.076 & 0.076 & 0.076 & 0.076 & 0.076 & 0.076 & 0.076 & 0.076 & 0.076 & 0.076 \\
D1 & 0.078 & 0.078 & 0.078 & 0.078 & 0.078 & 0.078 & 0.078 & 0.078 & 0.078 & 0.078 & 0.078 & 0.078 & 0.078 & 0.078 \\
D2 & 0.089 & 0.089 & 0.089 & 0.089 & 0.089 & 0.089 & 0.089 & 0.089 & 0.089 & 0.089 & 0.089 & 0.089 & 0.089 & 0.089 \\
D3 & 0.099 & 0.099 & 0.099 & 0.099 & 0.099 & 0.099 & 0.099 & 0.099 & 0.099 & 0.099 & 0.099 & 0.099 & 0.099 & 0.099 \\
\hline
\end{tabular}

\subsection{COLLATION OF WEIGHTS OF CONSTRUCTS AND CRITERIA}

First, we use the DANP to calculate the total-influence matrix and form the unweighted matrix for the constructs. Subsequently, it is multiplied with the previously calculated weights of the four major constructs (A: 0.2090 , B: 0.2743 , C: 0.2877 , and D: 0.2290 ) to constitute the weighted supermatrix and transposed matrix. Finally, the limiting calculation is conducted to compose the weights of criteria, which are presented in Table 8 .

Following the aforementioned DANP calculation procedure, the criteria weights are obtained, and we can determine the importance and weights of the constructs and criteria (Table 9).

From the results in Table 9, the importance of the four major constructs is computed for the primary factors affecting the switching of operational locations by container terminal operators at the Port of Kaohsiung. The findings indicate that the two most important constructs under the effect cluster are Construct $\mathrm{C}$ "The cost of switching" (0.288) and Construct B "The operation conditions of the terminals" $(0.274)$. This is because, eventually, for operational container terminals, successful switching depends on how terminal operates perceive the conditions of the terminals to be. It is still mainly the major terminal operates who are considering the quality of the terminal, how much port machinery and terminals will be invested in the migration process of the old and new terminals in the future, and before starting operations, the most important consideration of switching cost. Essentially, the two criteria, B2 "Limitation of ship type eligible for berthing at the terminals" (ranked third) and B3 "Appropriateness of the operation locations at the port" (ranked first), also fall under the effect cluster and have relatively high overall weights and rankings, indicating that under the trend of vessel upsizing, the key concern of carriers is to select the appropriate terminals that can accommodate their large vessels.

The constructs ranked immediately lower are Construct $\mathrm{D}$ "The connection with inland transportation" (0.229), ranked third, and Construct A "The overall planning of the port" (0.209), ranked fourth. These two constructs fall under the cause cluster, and their weights are not close to those of the first two constructs. After all, for terminal operators conducting the location switch, they must consider the connectivity of outbound transportation at the new terminal location as well as how they will cope with plans by the government or port operator (Port Company). In particular, the two criteria D3 "Neighboring locations of the container yards" (ranked second) and A1 "Safety of the operation locations at the port" (ranking fourth) have relatively high overall weights and rankings, indicating that, under the trend of vessel upsizing, the terminals to be selected must be at relatively advantageous locations in the port (e.g., deep-water terminals such as 4th, 5th, and 6th container center that are closer to Harbor 2). In addition, cooperation with neighboring container yards and the sharing of terminals will help attract various container vessels to berth and operate as they are key concerns for container carriers and terminal operators. 
Table 9: Main factors of switching of container terminal weights and ranking

\begin{tabular}{|c|c|c|c|c|c|c|}
\hline Construct & Weight & & Code and criterion content & $\begin{array}{r}\mathrm{Ov} \\
\text { weig } \\
\text { ran }\end{array}$ & & Cluster \\
\hline \multirow[t]{4}{*}{$\begin{array}{l}\text { A. The overall } \\
\text { planning of the port }\end{array}$} & $\begin{array}{l}0.209 \text { (Cause } \\
\text { cluster) }\end{array}$ & A1 & $\begin{array}{l}\text { Safety of the operation locations at } \\
\text { the port }\end{array}$ & 0.093 & 4 & Effect cluster \\
\hline & & A2 & $\begin{array}{l}\text { Continuity of the incentive and } \\
\text { subsidy mechanism of the port }\end{array}$ & 0.045 & 11 & Effect cluster \\
\hline & & A3 & $\begin{array}{l}\text { Compulsory competitive terms of } \\
\text { the public port }\end{array}$ & 0.042 & 12 & Effect cluster \\
\hline & & A4 & $\begin{array}{l}\text { Entirety of the overall planning of } \\
\text { new and old port areas }\end{array}$ & 0.077 & 7 & Cause cluster \\
\hline \multirow{4}{*}{$\begin{array}{l}\text { B. The operation } \\
\text { conditions of the } \\
\text { terminals }\end{array}$} & $\begin{array}{l}0.274 \text { (Effect } \\
\text { cluster) }\end{array}$ & B1 & $\begin{array}{l}\text { The sufficiency of routes berthing at } \\
\text { the terminals }\end{array}$ & 0.058 & 10 & Cause cluster \\
\hline & & B2 & $\begin{array}{l}\text { Limitation of ship type eligible for } \\
\text { berthing at the terminals }\end{array}$ & 0.094 & 3 & Effect cluster \\
\hline & & B3 & $\begin{array}{l}\text { Appropriateness of the operation } \\
\text { locations at the port }\end{array}$ & 0.108 & 1 & Effect cluster \\
\hline & & B4 & $\begin{array}{l}\text { Willingness to attract non-leasing } \\
\text { carriers to berth }\end{array}$ & 0.076 & 8 & Effect cluster \\
\hline \multirow[t]{3}{*}{$\begin{array}{l}\text { C. The cost of } \\
\text { switching }\end{array}$} & $\begin{array}{l}0.288(\text { Effect } \\
\text { cluster })\end{array}$ & $\mathrm{C} 1$ & Cost of equipment & 0.04 & 13 & Cause cluster \\
\hline & & $\mathrm{C} 2$ & Cost of site refinement & 0.027 & 14 & Cause cluster \\
\hline & & $\mathrm{C} 3$ & $\begin{array}{l}\text { Cost of switching intermediate } \\
\text { containers among terminals }\end{array}$ & 0.076 & 9 & Effect cluster \\
\hline \multirow{3}{*}{$\begin{array}{l}\text { D. The connection } \\
\text { with inland } \\
\text { transportation }\end{array}$} & $\begin{array}{l}0.229 \text { (Cause } \\
\text { cluster) }\end{array}$ & D1 & $\begin{array}{l}\text { The accessibility of outbound } \\
\text { transportation of the container yards }\end{array}$ & 0.078 & 6 & Cause cluster \\
\hline & & D2 & $\begin{array}{l}\text { Attraction and operation of } \\
\text { transshipment containers }\end{array}$ & 0.089 & 5 & Effect cluster \\
\hline & & D3 & $\begin{array}{l}\text { Neighboring locations of the } \\
\text { container yards }\end{array}$ & 0.099 & 2 & Effect cluster \\
\hline
\end{tabular}

\section{CONCLUSION}

Using Kaohsiung Port as an example to analyze the evolution of terminal upgrades and the shifting of terminal capacity. Issues related to carrier alliances, inadequate tugboats, route allocation, and port selection were not discussed. Policymakers of many major ports, such as those in Rotterdam, Hamburg, Singapore, and Shanghai, have anticipated future changes in maritime transport prior to investing in terminal upgrades. They do so particularly to adapt themselves to market needs. Despite the slowdown global trade, major container ports must invest in terminal upgrades to maintain their status as transport hubs. Although policies for the development of container terminal facilities differ between ports, new container terminals are undoubtedly emerging to replace old ones.
Furthermore, the orderly transition from old to new terminals is essential to the city's economic growth. Hence, port regulators and operators must develop a structured switch proposal when they collaborate with each other to ensure that the economic vitality and sustainability of ports and cities.

This study revealed that Kaohsiung faces external challenges, such as the rise of Chinese ports, the emerging trend toward mega vessels, the lack of new deep-water terminals, and new carrier alliances no longer perceiving the Port of Kaohsiung as their only base. Consequently, although the container throughput of the Port of Kaohsiung has increased, its rate of growth is overshadowed by those of emerging ports in East Asia and China. Hence, the port has lost its status as a continental 
hub port and is now a mere regional hub port. Despite the port's geographical advantages, port expansion is impeded by the sparse distribution of terminals, inadequate water depth, obsolete equipment, and limited business volume, especially considering the ostensibly stagnating growth rate of container quantity.

At present, the Port of Kaohsiung is less developed compared with other international ports in China and East Asia in terms of terminal size, equipment, and resources. If the currently operating container terminal in Kaohsiung Port is to be successfully switching, terminal operators must consider the various conditions of the terminal, such as: 1) whether the berthing facility and location of the terminal can operate large container ships; 2) the future shifting process between new and old terminals factors (i.e. how much to invest in terminal-related operating equipment costs); and 3)whether policies support are the most important considerations for shipping companies and terminal operators. Kaohsiung port must accelerate the construction of new deep-water terminals at 7 th container center. Once the operation of the 7 th container center wharf commences, the container terminals inside the port will undoubtedly be switching. The operation strategy, integration planning, exploration, and utilization of the container terminals will also be adjusted to effectively utilize port resources, thus strengthening the port's competitiveness. These efforts will thus attract carriers to consistently berth at the port. More importantly, these efforts are key to maintaining the status of the Port of Kaohsiung as a regional hub port.

\section{ACKNOWLEDGEMENTS}

This research was supported by Ministry of Science and Technology, Taiwan, ROC. Project No: number MOST 106-2410-H-992-304.

\section{REFERENCES}

1. ALPHALINER MONTHLY MONITOR (2020). https://www.alphaliner.com/resource/Alphaliner Monthly_Monitor_Jan_2020.pdf (Accessed $1^{\text {st }}$ Jan 2020)

2. CHAO, M. T., CHANG, Y. T. and LIN, L. J. (2018). An efficiency of container operation analysis in Kaohsiung port. Maritime Quarterly, Vol.27 No.3, pp. 81-105.

3. CHEN, C. Y. (2019). Impact of the deployment of main routes in the Asia-Pacific region on Kaohsiung Port. Proceedings of the Taiwan Port and Container Terminal Development Trend Seminar.

4. CHEN, C.Y., Yang, C. C., Tai, H. H and Chu, C. Y. (2015). The strategy of Kaohsiung Port under the new route. Harbour Quarterly, No.103, pp. P63-84.
5. CHINA NATIONAL SEAMEN SERVICE (CNSS) (2017). https://www.cnss.com.cn/ (Accessed March 2017).

6. DAVIDSON, N. (2016). Juggling bigger ships, mega-alliances and slower growth. Presented at the Terminal Operations Conference Europe. Hamburg, Germany, 14 June 2016.

7. Gomez Paz, M. A., Camarero Orive, A. and Cancelas, N. G. (2015). Use of the Delphi method to determine the constraints that affect the future size of large container ships. Maritime Policy \& Management, Vol.42 No.3, pp. 263 277.

8. HOLYE, B. S. (1989). The port-city interface: trends, problems and examples, 1989. Geoforum, Vol.20 No.4, pp. 429-435.

9. HSU, C. and HSIEH, Y. (2005). Direct versus hub and spoke routing on a maritime container network. Journal of Marine Science and Technology, Vol.13 No.3, pp. 209-217.

10. KADAIFCI, C., ASAN, U., SERDARASAN, S. and ARICAN, U. (2018). A new rule-based integrated decision making approach to container transshipment terminal selection. Maritime Policy \& Management, Vol.46 No. 2, pp. 237-256.

11. KAVIRATHNA, C. A., KAWASAKI, T. and HANAOKA, S. (2018). Transshipment hub port competitiveness of the port of Colombo against the major Southeast Asian hub ports. The Asian Journal of Shipping and Logistics, Vol.34 No. 2, pp. 71-82.

12. KIM, S. M. (1998). Economies of scale in container shipping. Maritime Policy \& Management, Vol.25, pp.361-373.

13. LAI, W. S. and LEE, H. (2018). Analysis of maritime policy in Taiwan performance review and result of survey. Transportation Planning Journal, Vol.47, pp.29-62.

14. LIN, C. J. and WU, W. W. (2008). A causal analytical method for group decision-making under fuzzy environment. Expert Systems with Applications, Vol.34 No.1, pp. 205-213.

15. LIN, D. Y. and TAI, H. H. (2016). The impact of trunk route deployment changes on pollutant emissions in international container shipping after Panama Canal expansion. The International Journal of Logistics Management (IJLM), Vol.27, pp. 335-352.

16. Liou, J. J. H., Tzeng, G. H., \& Chang, H. C. (2007). A novel hybrid model for safety measurement of airlines. Journal of Air Transport Management, 13(4), 243-249.

17. MINISTRY OF TRANSPORTATION AND COMMUNICATION (MOTC) (2013). Terminal Pattern for the Change of Environment of Taiwan Container Port Operation. MOTC, MOTC-IOT-101-H-1DB001a, Institute of Transportation, Taiwan. 
18. MINISTRY OF SCIENCE AND TECHNOLOGY (MOST) (2017). The Analysis of Influence and Scenario Plans of Shifting on Container Terminals of Kaohsiung Port, MOST106-2410 -H022- 004, Institute of Transportation, Taiwan.

19. MINISTRY OF TRANSPORTATION AND COMMUNICATION (MOTC) (2015). The Integrated Overall Development Plan of Taiwan's Ports (2017-2021). MOTC-IOT-104ED003, Institute of Transportation, Taiwan.

20. MINISTRY OF TRANSPORTATION AND COMMUNICATION (MOTC) (2016). A Study of Adaptive Capacity Strengthened for Taiwan Container Ports. MOTC, MOTC-IOT-104$H 1 D B 005 a$, Institute of Transportation, Taiwan.

21. MINISTRY OF TRANSPORTATION AND COMMUNICATION (MOTC) (2017a). The Analysis of Container Terminals on Operational Tendencies and Capacity-utility of Taiwanese Container Ports. MOTC, MOTC-IOT-105H1EB005a, Institute of Transportation, Taiwan.

22. MINISTRY OF TRANSPORTATION AND COMMUNICATION (MOTC) (2017b). $A$ Source and Shipping Patterns Analysis of the Transshipping Containers on Kaohsiung Harbor, MOTC-IOT-105- H1DA005a, Institute of Transportation, Taiwan.

23. OU YANG, Y. P., SHIEH, H. M., LEU, J. D. and TZENG, G. H. (2008). A novel hybrid MCDM model combined with DEMATEL and ANP with applications. International Journal of Operations Research, Vol.5 No.3, pp. 1-9.

24. PARK, N. K. and SUH, S. C. (2019). Tendency toward mega containerships and the constraints of container terminals. Journal of Marine Science, Vol.7, pp. 131.

25. QIANG, M., JINXIAM, W. and SUYI, L. (2017). Impact analysis of mega vessels on container terminal operations. Transportation Research Procedia, Vol.25, pp. 187-204.

26. SAATY, T.L., (1999). Fundamentals of the analytic network process. In. The International Symposium on the Analytic Hierarchy Process. Japan, Kobe.

27. SU, D. T., HSIEH, C. H. and TAI, H. H. (2016). Container hub-port vulnerability: Hong Kong, Kaohsiung and Xiamen. Journal of Marine Engineering and Technology, Vol.15, pp. 19-30.

28. TAI, H. H. (2012). The influence on transshipment function of Kaohsiung port by the trunk-route developments in the East Asia and cross-strait direct shipping. Transportation Planning Journal, Vol.41, pp. 435-463.

29. TAI, H. H. (2015). A comparative study on pollutant emissions and hub-port selection in Panama Canal expansion. Maritime Economics and Logistics, Vol.17, pp. 163-178.

30. TAI, H. H. (2016). Analysis of the operation trends and future countermeasures of container terminals in Taiwan. Proceedings of the Taiwan Port and Container Terminal Development Trend Seminar, P3-1.

31. TAI, H. H., CHEN, C. Y., YANG, C. C. and HSIEH, Y. P. (2014). Evaluation of container terminal operations model in Taiwan after port corporatization. Transportation Planning Journal, Vol.43, pp. 1-32.

32. TAI, H. H. and HWANG, C. C. (2005). Analysis of hub port choice for container trunk lines in East Asia. Journal of the Eastern Asia Society for Transportation Studies, Vol.6, pp. 907-919.

33. TAI, H. H. and TSAI, T. Y. (2019). The evaluation of competitiveness on cost advantage of regional hub port: the case study of TransPacific route against Kaohsiung port. International Journal of Maritime Engineering, Vol.161, pp. 381-400.

34. TAI, H. H. and YANG, C. C. (2016). A policymaking framework for enhancing Kaohsiung port's economic resilience. International Journal of Maritime Engineering, Vol.158, pp. A347A358.

35. TAI, H. H. and YANG, C. C. (2017). Contingency strategy for container terminal industry in Kaohsiung Port. Cross-Strait Shipping Logistics Seminar 2017, pp. 1-13.

36. TSAI, T. Y. and TAI, H. H. (2019b). The outlook of deep-water container terminal at the port of Kaohsiung. Presented at 10th International Forum on Shipping, Ports and Airports (IFSPA), Hong Kong, pp. 50-68.

37. TZENG, G. H., CHIANG, C. H. and LI, C. W. (2007). Evaluating intertwined effects in $e$ learning programs: a novel hybrid MCDM model based on factor analysis and DEMATEL. Expert Systems with Applications, Vol.32, pp. 1028-1044.

38. UNITED NATIONS CONFERENCE ON TRADE AND DEVELOPMENT (2019). Review of Maritime Transport 2019, United Nations, New York.

39. VEGA, L., CANTILLO, V. and ARELLANA, J. (2019). Assessing the impact of major infrastructure projects on port choice decision: the Colombian case. Transportation Research Part A, Vol.120, pp. 132-148.

40. WANG, K. Y. (2016). The Impacts of Container Shipping and Port Development on Kaohsiung Harbor, Minister of Transportation and Communication (MOTC), Taiwan.

41. WANG, Y. T. (2015). Operational performance of container terminals at the port of Kaohsiung. Maritime Quarterly, Vol.24, pp. 45-59.

42. WU, Y. (2016). The impact of global container carriers' merge and acquisition as well as reorganization of strategic alliances on the demand for container terminal services in Taiwan. Taiwan Port and Container Terminal Development Trend Seminar. 
43. WU, W. W. and LEE, Y. T. (2007). Developing global managers' competencies using the fuzzy DEMATEL method. Expert Systems with Applications, Vol.32, pp. 499-507.

44. XU, C. Y., HU, Y. C. and SONG, R. P. (2015). Discussion on port planning and construction and ship navigation safety. Journal of Taiwan
Maritime Safety and Security Studies, Vol.6 No.5, pp. 27-56.

45. YAP, W. Y. and ZAHRAEI, S. M. (2018). Liner shipping alliances and their impact on shipping connectivity in Southeast Asia. Maritime Business Review, Vol.3, pp. 243-255.

\section{APPENDIX: STATISTICAL OF EXPERT QUESTIONNAIRES IN THIS STUDY}

APPENDIX A: IMPORTANT CONSTRUCTS MEANS AND STANDARD DEVIATION

A1. Means

\begin{tabular}{c|cccc} 
& $\mathrm{A}$ & $\mathrm{B}$ & $\mathrm{C}$ & $\mathrm{D}$ \\
$\mathrm{A}$ & & 1.70 & 2.60 & 1.40 \\
$\mathrm{~B}$ & 1.30 & & 1.20 & 1.40 \\
$\mathrm{C}$ & 0.50 & 1.00 & & 0.60 \\
$\mathrm{D}$ & 1.10 & 1.60 & 1.00 & \\
\hline
\end{tabular}

A2. Standard Deviation

\begin{tabular}{c|cccc} 
& $\mathrm{A}$ & $\mathrm{B}$ & $\mathrm{C}$ & $\mathrm{D}$ \\
$\mathrm{A}$ & & 1.34 & 0.84 & 0.97 \\
$\mathrm{~B}$ & 0.95 & & 1.14 & 0.84 \\
$\mathrm{C}$ & 0.53 & 0.94 & & 0.84 \\
$\mathrm{D}$ & 0.74 & 0.70 & 0.94 & \\
\hline
\end{tabular}

APPENDIX B : IMPORTANT CRITERIA AND FACTORS MEANS AND STANDARD DEVIATION

B1 Means

\begin{tabular}{l|cccccccccccccc} 
& $\mathrm{A} 1$ & $\mathrm{~A} 2$ & $\mathrm{~A} 3$ & $\mathrm{~A} 4$ & $\mathrm{~B} 1$ & $\mathrm{~B} 2$ & $\mathrm{~B} 3$ & $\mathrm{~B} 4$ & $\mathrm{C} 1$ & $\mathrm{C} 2$ & $\mathrm{C} 3$ & $\mathrm{D} 1$ & $\mathrm{D} 2$ & $\mathrm{D} 3$ \\
$\mathrm{~A} 1$ & & 0.00 & 0.00 & 2.67 & 1.50 & 3.67 & 3.67 & 2.17 & 0.00 & 0.00 & 0.67 & 1.67 & 1.00 & 2.00 \\
$\mathrm{~A} 2$ & 0.83 & & 0.00 & 0.00 & 2.33 & 1.00 & 0.00 & 1.33 & 1.00 & 0.00 & 1.17 & 0.00 & 2.17 & 0.00 \\
$\mathrm{~A} 3$ & 0.17 & 1.00 & & 1.00 & 0.83 & 1.00 & 1.00 & 2.83 & 0.00 & 0.00 & 2.00 & 0.00 & 1.00 & 0.00 \\
$\mathrm{~A} 4$ & 2.83 & 1.17 & 0.00 & & 1.33 & 3.17 & 3.00 & 2.17 & 1.00 & 1.00 & 2.17 & 2.00 & 2.00 & 2.00 \\
$\mathrm{~B} 1$ & 2.83 & 2.17 & 2.00 & 1.00 & & 2.17 & 2.00 & 2.17 & 0.00 & 0.00 & 1.00 & 2.00 & 2.67 & 3.33 \\
$\mathrm{~B} 2$ & 2.83 & 1.00 & 1.00 & 1.00 & 0.00 & & 3.00 & 2.00 & 3.67 & 2.00 & 1.00 & 1.00 & 1.00 & 2.00 \\
$\mathrm{~B} 3$ & 2.67 & 0.00 & 1.00 & 3.00 & 1.17 & 2.00 & & 1.00 & 2.00 & 2.33 & 2.00 & 3.17 & 2.00 & 3.00 \\
$\mathrm{~B} 4$ & 1.00 & 0.17 & 1.83 & 1.00 & 1.00 & 2.00 & 2.00 & & 0.00 & 0.00 & 1.17 & 2.00 & 2.67 & 2.67 \\
C1 & 1.17 & 1.00 & 1.33 & 0.00 & 2.33 & 3.00 & 1.33 & 1.33 & & 0.00 & 1.00 & 1.00 & 1.00 & 2.00 \\
C2 & 1.00 & 1.00 & 2.00 & 2.00 & 2.17 & 2.33 & 3.00 & 2.00 & 1.00 & & 1.00 & 1.83 & 2.00 & 2.00 \\
C3 & 1.17 & 2.67 & 2.00 & 3.00 & 1.17 & 1.00 & 3.00 & 1.00 & 1.67 & 0.00 & & 1.83 & 3.00 & 3.00 \\
D1 & 3.50 & 0.00 & 0.83 & 3.67 & 1.17 & 1.67 & 3.00 & 3.17 & 0.00 & 0.00 & 2.00 & & 3.17 & 3.67 \\
D2 & 1.83 & 3.50 & 1.00 & 0.00 & 2.17 & 2.00 & 3.00 & 1.00 & 0.00 & 1.00 & 3.67 & 2.00 & 2.00 \\
D3 & 2.50 & 0.00 & 0.00 & 2.00 & 1.83 & 2.00 & 2.00 & 1.00 & 0.00 & 0.00 & 2.00 & 2.00 & 2.00 &
\end{tabular}


B2. Standard Deviation

\begin{tabular}{l|ccccccccccccccc} 
& $\mathrm{A} 1$ & $\mathrm{~A} 2$ & $\mathrm{~A} 3$ & $\mathrm{~A} 4$ & $\mathrm{~B} 1$ & $\mathrm{~B} 2$ & $\mathrm{~B} 3$ & $\mathrm{~B} 4$ & $\mathrm{C} 1$ & $\mathrm{C} 2$ & $\mathrm{C} 3$ & $\mathrm{D} 1$ & $\mathrm{D} 2$ & $\mathrm{D} 3$ \\
$\mathrm{~A} 1$ & & 0.00 & 0.00 & 0.52 & 0.84 & 0.52 & 0.52 & 0.41 & 0.00 & 0.00 & 0.52 & 0.52 & 0.00 & 0.00 \\
$\mathrm{~A} 2$ & 1.60 & & 0.00 & 0.00 & 0.52 & 0.00 & 0.00 & 0.82 & 0.00 & 0.00 & 0.41 & 0.00 & 0.41 & 0.00 \\
$\mathrm{~A} 3$ & 0.41 & 0.00 & & 0.00 & 0.41 & 0.00 & 0.00 & 0.41 & 0.00 & 0.00 & 0.00 & 0.00 & 0.00 & 0.00 \\
A4 & 0.41 & 0.41 & 0.00 & & 0.52 & 0.41 & 0.00 & 0.41 & 0.00 & 0.00 & 0.41 & 0.00 & 0.00 & 0.00 \\
B1 & 0.41 & 0.41 & 0.00 & 0.00 & & 0.41 & 0.00 & 0.41 & 0.00 & 0.00 & 0.00 & 0.00 & 0.52 & 1.03 \\
B2 & 0.41 & 0.00 & 0.00 & 0.00 & 0.00 & & 0.00 & 0.00 & 0.52 & 0.00 & 0.00 & 0.00 & 0.00 & 0.00 \\
B3 & 0.82 & 0.00 & 0.00 & 0.00 & 0.41 & 0.00 & & 0.00 & 0.00 & 0.82 & 0.00 & 0.41 & 0.00 & 0.00 \\
B4 & 0.00 & 0.41 & 0.41 & 0.00 & 0.00 & 0.00 & 0.00 & & 0.00 & 0.00 & 0.41 & 0.00 & 0.52 & 0.52 \\
C1 & 0.41 & 0.00 & 0.82 & 0.00 & 0.52 & 0.00 & 0.52 & 0.52 & & 0.00 & 0.00 & 0.00 & 0.00 & 0.00 \\
C2 & 0.00 & 0.00 & 0.00 & 0.00 & 0.41 & 0.82 & 0.00 & 0.00 & 0.00 & & 0.00 & 0.41 & 0.00 & 0.00 \\
C3 & 0.41 & 0.52 & 0.00 & 0.00 & 0.41 & 0.00 & 0.00 & 0.00 & 0.52 & 0.00 & & 0.41 & 0.00 & 0.00 \\
D1 & 0.84 & 0.00 & 0.41 & 0.52 & 0.41 & 0.52 & 0.00 & 0.41 & 0.00 & 0.00 & 0.00 & & 0.41 & 0.52 \\
D2 & 0.41 & 0.84 & 0.00 & 0.00 & 0.41 & 0.00 & 0.00 & 0.00 & 0.00 & 0.00 & 0.52 & 0.00 & \\
D3 & 0.84 & 0.00 & 0.00 & 0.00 & 0.41 & 0.00 & 0.00 & 0.00 & 0.00 & 0.00 & 0.00 & 0.00 & 0.00 & 0.00
\end{tabular}

